\title{
Climate protection in Polish legal system
}

Since there is a great interest on the subject of climate protection in the world, it is necessary to make attempts at legal analysis of notions connected with it. It can be noticed that also other scientific disciplines, especially climatology, biology, ecology as well as economy, are interested in climate protection. But legal problems are often forgotten in scientific analysis. The law plays a significant role in climate protection, however not a leading one.

From the point of view of natural environment management climate protection is important. 'Natural environment management uses the resources and advantages of nature in order to satisfy individuals' needs and social needs (from local communities to nations) with simultaneous:

- limiting losses and maintaining the greatest care in transforming ecosystems or geological formations at acquiring renewable resources;

- supporting natural processes undergoing anthropopression while using renewable resources in order to guarantee the stability and permanence and efficiency of their functioning ${ }^{11}$.

* Doctor with a post-doctoral academic title in environmental protection law, Manager of the Department of Environmental Protection Law of Nicolaus Copernicus University in Torun - Poland, Legal adviser.

1 B. Podskrobko, [in:] B. Podskrobko (ed.), Zarzqdzanie środowiskiem, Warsaw 2007, p. 10. 


\section{Bartosz Rakoczy}

It is also noticed that environmental recovery is significant for environmental protection. 'Environmental recovery, understood as the process of maintaining the socially accepted quality for future generations as well as maintaining self-regulating abilities of given ecosystems, requires bearing specific costs ${ }^{2}$

These scientific deliberations in legal sciences concern mostly the analysis of international public law as well as the European law ${ }^{3}$. However, attempts to analyse legal solutions accepted in legal systems of different countries are not undertaken ${ }^{4}$. It can be justified by the fact that the most efficient climate protection can be carried out in the international legal field, whereas in the field of national law it is the least efficient. It is often forgotten that subjects from whom specific behaviour concerning climate protection is required, work mostly on the basis of legal articles of a given country. It is the 'first contact law', which directly specifies a legal situation of an individual. On the basis of these norms public administration bodies specify the legal situation of individuals, above all entrepreneurs. This is the reason why the analysis of legal solutions accepted in different countries is justified and necessary.

This article is aimed at presenting various legal solutions concerning climate protection in the Polish law which is an example of legal solutions in a given, particular legal system.

To start with, it should be pointed out that in the Polish law a separate division dealing only with climate protection has not been worked out either in legal regulations or in the doctrine. It does not mean that the Polish law does not comprise autonomy concerning climate protection. However, the regulations are not so important and so numerous that one could treat them as a separate division of the environmental protection law. As the Environmental Protection Act ${ }^{5}$ says (article 9 section 39 of the

2 B. Fiedor, in: B. Fiedor (ed.) Podstawy ekonomii środowiska $i$ zasobów naturalnych, Warsaw 2002, p. 198.

3 See among others the latest publications of H. J. Hans, H. H. B. Vedder, European Environment Law, ed. 3, Groningen 2008.

${ }^{4}$ J. Boć (ed.) K. Nowacki (ed.) Prawna ochrona powietrza i handel uprawnieniami emisyjnymi w Polsce i Niemczech, Colony 2006, referred further to as J. Boć (ed.), K. Nowacki (ed.), Prawna ochrona, contains interesting deliberation. See also: G. Dobrowolski, Ochrona powietrza. Zagadnienia administracyjnoprawne, Cracow 2000.

5 Journal of Laws of 2008, No 25 item, 150 with amendments, further referred to as Environmental Protection Act. 
act dated on 27 April 2001) 'environment is the whole of environmental elements, including the ones transformed due to activity of a human being, in particular the surface of the Earth, ore, water, air, landscape, climate and other elements of natural diversity as well as mutual influences between these elements'.

As it has been pointed out in the doctrine of the environmental protection law, this definition consists of two parts. The first part describes the environment in a general way. The Polish legislator points out that environment is the whole of environmental elements, also the ones transformed due to the activity of a human being. However, in the other part the legislator enumerates all environmental elements which make up 'environment'. The elements mentioned in this definition are only of a model character and this catalogue should not be treated as comprehensive $e^{6}$.

The Polish legislator uses the notion 'climate' in the ruling described above, although it does not define it. In biological and geographical sciences it is pointed out that climate is 'the regularity and consequence of atmospheric processes happening as a result of solar radiation, the circulation of air and the ground properties conditioning the characteristic weather system in a given place. [...] Climate's most important elements are: atmospheric pressure, temperature, precipitation, wind, air humidity and cloudiness'.

The most important is the fact that climate is treated as an environmental element in the Polish legal system. The Polish legislator acknowledges that climate is a part of environment. It means that all legal regulations concerning environmental protection also refer to climate. Thus there is no need to treat the notion of climate separately. On the other hand, however, it should be noticed that climate is a complex notion, which consists of numerous elements. The legislator should take into consideration the climate's complexity, which is the outcome of several factors. As a consequence, climate protection should mainly consist of regulating the elements making

6 See: B. Wierzbowski, B. Rakoczy, Podstawy prawa ochrony środowiska, ed. III, Warszawa 2007; K. Gruszecki, Prawo ochrony środowiska. Komentarz, ed. II, Warszawa 2008, B. Rakoczy, in: J. Ciechanowicz-McLean, Z. Bukowski, B. Rakoczy, Prawo ochrony środowiska. Komentarz, Warszawa 2008, A. Lipiński, Prawne podstawy ochrony środowiska, ed. IV, Warszawa 2008.

7 G. Łabno, Ekologia. Stownik encyklopedyczny, Kraków 2006, p. 160. 


\section{Bartosz Rakoczy}

climate, preventing or restricting the disturbance of them or diminishing the influence.

Legal regulations concerning climate protection can also be seen in the Constitution of the Republic of Poland dated on 2 April 1997. In the first place it should be noticed that the article 5 of the Constitution of the Republic of Poland says that "The Republic of Poland shall safeguard the independence and integrity of its territory and ensure the freedoms and rights of persons and citizens, the security of the citizens, safeguard the national heritage and shall ensure the protection of the natural environment pursuant to the principles of sustainable development ${ }^{\text {'9 }}$.

This regulation plays an essential role in the Polish environmental protection law because it shows that the environmental protection, including climate protection, is one of the most important tasks of the government. The principle of sustainable development has a very special meaning here. This principle assumes integration and coexistence of values which are in conflict with each other, at the same time one of these values being environmental protection.

Climate protection is about the conflict between environmental protection, economic development and economic needs. The greatest threat for climate and its protection is emission of carbon dioxide. This emission, and even the pollution, are the result of business activity and industrial needs.

It is not possible to eliminate the emission of carbon dioxide because it could harm justified economic development. However, according to the principle of sustainable development it is reasonable to limit the emission of harmful substances in order to protect the environment, in that specific case, the climate.

When it comes to climate protection, the sustainable development principle is in accordance with values specified in the preamble to the Constitution of the Republic of Poland. The preamble to the Constitution of Poland points out such circumstances as, beholden to our ancestors for their labours, their struggle for independence achieved at great sacrifice, for

\footnotetext{
8 Journal of Laws, No 78, item 483 with amendments, further referred to as The Constitution of the Republic of Poland.

9 See further details on constitutional bases of environmental protection law in: B. Rakoczy, Die Problematik der Umweltschutzgrundlagen in der polnischen Verfassung, Zeitschrift für Europäisches Umwelt - und Planungsrecht, 2005, booklet 1, p. 12-16.
} 
our culture rooted in the Christian heritage of the Nation and in universal human values',

[...] 'Obliged to bequeath to future generations all that is valuable from our over one thousand years' heritage',

$[\ldots]$

'Aware of the need for cooperation with all countries for the good of the Human Family.'

Article 74 of the Constitution of the Republic of Poland should be also taken into consideration while analysing the constitutional regulations. According to this regulation:

'1. Public authorities shall pursue policies ensuring the ecological security of current and future generations.

2. Protection of the environment shall be the duty of public authorities.

3. Everyone shall have the right to be informed of the quality of the environment and its protection.

4. Public authorities shall support the activities of citizens to protect and improve the quality of the environment'.

This regulation, however, does not refer directly to climate protection. It also contains important elements referring to this notion. It regulates the duty of authorities to adopt the policy ensuring ecological safety for contemporary and future generations. Ecological safety seems to be the most important notion from the discussed point of view. The Constitutional Tribunal explained the meaning of this notion in the judgement dated on 6 June 2006 K 23/05. In the justification of this judgement the Tribunal says that: 'the notion of «ecological safety» should be understood as obtaining such a state of environment which allows to reside in it and enables using it in a way ensuring human development. Environmental protection is one of elements of "ecological safety" but obligations of public authorities are wider - they also cover activities improving the contemporary condition of environment and programming its further development. The basic method of achieving such an aim is - as ordered by article 5 of the Constitution of the Republic of Poland - to be guided by the principle of sustainable development which refers to international decisions, especially to the conference in Rio de Janeiro in 1992 (compare J. Boć, [in:] Konstytucje Rzeczpospolitej Polskiej oraz komentarz do Konstytucji Rzeczpospolitej Polskiej of 1997, ed. by J. Boć, Wrocław 1998, p. 24 and next). The principle of sustainable development covers not only nature protection or spatial order but also proper concern for social development and development concerning civilization, connected with the necessity to build appropriate infrastructure, 


\section{Bartosz Rakoczy}

indispensable for - taking civilization needs into consideration - the life of human beings and individual communities. Thus the idea of sustainable development contains the need to consider various constitutional values and its proper balance.'

Article 74 of the Constitution of Poland also says that the very public authorities have the obligation to protect environment. As a consequence, Polish public authorities are responsible for the condition of climate and its protection, of course in such a range that is within their abilities.

It should also be noticed that the public authorities are obliged to support citizens' actions concerning improvement and protection of environment, including climate protection.

On the other hand, however, article 74 of the Constitution of the Republic of Poland says that everyone shall have the right to be informed of the quality of the environment and its protection as well as all the actions undertaken in order to protect the climate.

Article 86 of the Constitution of the Republic of Poland should be treated as the basis of climate protection. It says that: 'everyone shall care for the quality of the environment and shall be held responsible for causing its degradation. The principles of such responsibility shall be specified by statute.' This responsibility also refers to a direct risk of damage to climate and to causing a damage to it.

On the other hand, article 68 section 4 of the Constitution of the Republic of Poland states that 'Public authorities shall combat epidemic illnesses and prevent the negative health consequences of degradation of the environment.'

This ruling is so important because it can be clearly seen that the Polish constitutional legislator can see the connection between environmental protection and health protection. It means that environmental protection, including climate protection, is strictly connected with health protection.

The basic legal act in the Polish legal system which regulates the notions of environmental protection is the Environmental Protection Act. This act refers to climate only once. This notion occurs in article 127 of the Environmental Protection Act which states that ' 1 . Fauna and flora protection consists in:

7) afforesting and creating green areas, especially if it is necessary to protect the soil or animals, to shape climate or other needs connected with ensuring biological diversity, ecological balance and satisfying recreational needs of human beings'. 
It can be clearly seen that the legislator can see the connection between the protection of climate and flora and fauna since they take into account the fact that afforesting and creating concentrations of flora influences the quality of climate. Thus the protection of aforementioned natural elements influences the quality of elements of which climate consists.

However, the Environmental Protection Act also consists of other legal instruments concerning climate protection. In the Polish legal system the most important legal instrument of climate protection is the emission permit, especially the one referring to greenhouse gases. Integrated permit plays a special role since it takes into consideration not only restrictions on affecting the environment but also an obligation to use the best techniques available and achieving a high level of environmental protection ${ }^{10}$.

Another important instrument of climate protection are financial and legal means, above all fees and ecological taxes which are connected with the size of emission. As Z. Bukowski and K. Nowacki say "they are factors encouraging to diminish the emission by limiting the costs of activity. ${ }^{11}$

As the aforementioned article 127 of the Environmental Protection Act says, the notion of climate appears together with flora protection since plants are the basic organisms absorbing carbon dioxide and other greenhouse gases in natural way. Also in such a context,

the act on environmental protection dated on 16 October $2004^{12}$ should be treated as a legal act indirectly protecting climate through trees, bushes, green belt and tree-covered areas protection. The Polish legislator protects trees and bushes as well as green belt and tree-covered areas in this act. Article 5 of this act states that the green belt is 'areas and technical infrastructure as well as buildings functionally connected with one another, covered with flora, which can be found within rural areas of high-density, towns or cities performing aesthetic, recreational, health or protective functions, in particular parks, squares, embankments, promenades, botanical gardens, children playground, zoological and historic gardens as well as cemeteries,

10 See further details in: Z. Bukowski, Pozwolenie zintegrowane, Włocławek-Toruń 2004, p. 45.

${ }_{11}$ Z. Bukowski, K. Nowacki, in: J. Boć (ed.), K. Nowacki (ed.), Prawna ochrona, p. 156.

12 See further details in: K. Gruszecki, Ustawa o ochronie przyrody. Komentarz, Warszawa 2005, p. 304 and next; W. Radecki (ed) Teoretyczne podstawy prawa ochrony przyrody, Wrocław 2006; D. Trzcińska, in: J. Ciechanowicz-McLean (ed) Polskie prawo ochrony przyrody, Warszawa 2006, p. 88 and next; W. Radecki, Ustawa o ochronie przyrody. Komentarz, Warszawa 2008, p. 235. 


\section{Bartosz Rakoczy}

green areas surrounding streets, squares, historic fortifications, buildings, storage yards, airfields and railway and industrial facilities.' According to this definition the green belt has a protective function when health is concerned, which means that the green belt is created and maintained in order to use natural, absorbing properties of plants ${ }^{13}$.

The basic legal act concerning climate protection in Polish legal system is the act on substances impoverishing the ozone layer dated on 20 April $2004^{14}$. Indeed, this act does not refer directly to climate but its contents say that the basic aim of regulations is the protection of the ozone layer. The ozone layer is an indispensable factor influencing the quality of climate.

The basic regulations in the act on substances are the ones referring to obligations of subjects using controlled substances and products, machines and fittings using controlled substances. These are mostly obligations aimed at restricting the production and use of substances threatening the ozone layer. Fulfilling this obligation is connected with the necessity to gain the certificate of competence as well as keeping a record of produced and used substances.

This act also embraces notions connected with controlling subjects using and producing such substances.

Another legal act concerning climate protection in Polish legal system is the act dated on 22 December 2004 on trading entitlements to the emission of greenhouse gases and other substances to the atmosphere ${ }^{15}$.

This act specifies the rules of GHG and other substances entitlements trading system which aim is to limit such emissions in cost-effective and economically effective way.

The axiological basis of this act forms an assumption connected with the possible level of absorption of greenhouse gases by the environment. A specified level of emission of greenhouse gases is permissible, but this level should be specified in such a way that the environment could be able to absorb these gases and to cause self-purification. That is the reason why it is necessary to specify the level of absorption. However, who and when covers this permissible level of greenhouse gases emission is of secondary importance.

13 Journal of Laws, No 121 item 1263 with amendments, further referred to as the act on substances.

14 Journal of Laws No 121, item 1263 with amendments, further referred to as the act on substances.

15 Journal of Laws, No 167 item 1399 with amendments, further referred to as the act on health resorts. 
It should be also noticed that restricting greenhouse gases emission to environment by specifying the highest level of emission is aimed at climate protection because it is the GHG emission that endangers climate the most.

On the other hand, according to the sustainable development principle total elimination of greenhouse gases is not permissible. The Polish legislator points out that emission trading is aimed at reducing GHG emission and not its elimination. The legislator also suggests that GHG reducing should be performed in economically effective and cost-effective way. Thus it makes emission trading conditional on economy. Emission trading must be profitable and cannot lead to any economical disruptions.

This profitability and necessity to gain economical effects also means applying legal instruments aimed at reducing greenhouse gases emission to environment. So it is about achieving this effect by accepting such normative solutions which would be profitable for entrepreneurs.

Regulations included in the act on Medical Care in Health Resorts, Health Resorts and Protected Health Resort Areas and Municipalities dated on 8 July 2005 should be treated as important normative solutions concerning climate and health resort protection ${ }^{16}$.

This act concerns climate protection without any doubt but in a micro dimension. Previously presented legal acts were aimed at climate protection in a macro dimension. They concerned climate in which people live, too. So the aim was to protect climate as a natural factor influencing life and health of a human being.

In case of the health resort act it is about achieving a different aim but also the one connected with climate protection. However in this act microclimate protection should be treated as priority due to its specific features. These specific features of microclimate are used in medical and therapeutic purposes. It is about climate protection in a micro dimension.

As article 2 of the Act on Medical Care in Health Resorts, Health Resorts and Protected Health Resort Areas and Municipalities says 'expressions used in this act mean:

9) medical properties of climate - atmospheric properties which are in favour of maintaining in good health, treating or relieving effects or symptoms of diseases'.

16 Journal of Laws, No 167, item 1399 with amendments, further referred to as the act on health resorts. 


\section{Bartosz Rakoczy}

It can be clearly seen that these medical features of climate, i.e. atmospheric factors being in favour of maintaining good health, are the most important reason why the act on health resorts protects the climate.

The condition under which a place can be regarded as a health resort is the fact if it has climatic medical values. According to the article 36 of the Act on Medical Care in Health Resorts, Health Resorts and Protected Health Resort Areas and Municipalities:

'1. A district appeals to entitled units for confirmation of medical properties of climate and natural healing resources. Districts appeal for awarding the status of health resort or the status of health resort protection area.

2. Units entitled by the Minister of Health confirm medical properties of climate and natural healing resources on the basis of carried out researches.

3. Confirmation of medical properties of climate and natural healing resources is carried out on the basis of documented researches confirming these properties and excluding their negative effect on human organisms.

4. An entitled unit, aforementioned in section 2 , issues a certificate documenting the confirmation of medical properties of climate and natural healing resources.'

To sum up, climate protection in Polish legal system occurs within environmental protection. Climate is treated as an element of environment in the Polish law. It is a subject of protection as an element of environment. As a consequence, there is no need to make completely separate regulations concerning climate protection.

The legal basis of climate protection in the Polish law can be found in the Constitution of the Republic of Poland, above all in the constitutional principle of sustainable development and in constitutionally specified obligations of public authorities concerning environmental protection.

Climate protection is the protection of these elements which climate, being a complex phenomena, consists of. The environmental protection law contains the basic legal instruments.

The act on substances and emission trading are the basic legal acts. Microclimate is protected in a separate act, i.e. the act on health resorts.

The act on nature protection is very important in climate protection, especially the rulings concerning the green belt, wood lot, trees or bushes. 